\title{
Varia
}

„Kwartalnik Filmowy” nr 111 (2020)

ISSN: 0452-9502 (Print) ISSN: 2719-2725 (Online)

https://doi.org/10.36744/kf.376

(c) Creative Commons BY-NG-ND 4.0

Justyna Hanna Budzik

Uniwersytet Śląski

https://orcid.org/0000-0001-9740-0761

\section{O budowaniu mostów między teorią a praktyką humanistyki w edukacji filmowej}

\author{
Slowa kluczowe: \\ edukacja filmowa; \\ nowa humanistyka; \\ kształcenie \\ humanistyczne
}

\begin{abstract}
Abstrakt
Autorka podejmuje namysł nad miejscem edukacji filmowej w szerszym kontekście teoretycznym, odwołując się do koncepcji pedagogiki sytuacjonistycznej Tadeusza Sławka oraz osadzając ją w ramach nowej humanistyki. Jako studium przypadku omawia i analizuje wybrane działania z 35-letniej historii Centralnego Gabinetu Edukacji Filmowej. Komentarze do pomysłów Gabinetu autorka odnosi do europejskich strategii edukacji filmowej: wypracowanych przez British Film Institute oraz funkcjonujacych we Francji. W zakończeniu artykułu zostało sformułowanych pięć celów edukacji filmowej, które łączyłyby projekty z tego obszaru z kształceniem humanistycznym.
\end{abstract}


Pedagogika musi sprostać fundamentalnej sytuacji ludzkiej kondycji: egzystujemy nieuchronnie otoczeni i wspóttworzeni przez nieprzewidywalne przypadki i zdarzenia losu. (...) Uczenie $i$ wychowywanie to szkoła sytuowania się wobec zrzadzeń losu i przypadkowych okoliczności.

Tadeusz Sławek ${ }^{1}$

\section{Edukacja filmowa wobec (nowej) humanistyki}

Cele edukacji wytyczają fundamentalne pytania: po co i jakimi metodami chcemy nauczać lub się uczyć? Namysł nad nimi powinien poprzedzać formułowanie spodziewanych rezultatów kształcenia, opracowanie programów oraz wyliczanie metod i technik, którymi chcielibyśmy owe efekty osiągnać. Odpowiedź na pytanie o cel edukacji będzie zawsze nacechowana etycznie i będzie wynikała z postawy filozoficznej, którą reprezentuje osoba owe cele definiująca. Kiedy mówimy o trzech sferach edukacji (formalnej, pozaformalnej i nieformalnej) oraz o uczeniu się przez całe życie, mamy na myśli zdobywanie wiedzy, doskonalenie kompetencji oraz kształtowanie postaw wpływających na życie każdego człowieka i wspólnoty, którą współtworzy. Dlatego też, zastanawiając się nad umiejętnościami, które powinna gwarantować przemyślana i drobiazgowo zaplanowana edukacja filmowa, należy mieć na uwadze szerszą perspektywę rozumienia nauczania i misji leżącej u jego podstaw.

Stoję na stanowisku, że edukacja filmowa łącząca tradycyjnie już wyróżniane uczenie przez film, o filmie oraz dla filmu zawiera się w kształceniu humanistycznym, do którego należy zaliczyć także edukację literacką artystyczną czy kulturalną. Kształcenie humanistyczne jest zaś częścią pedagogiki w ogóle, dlatego też mottem tego artykułu uczyniłam słowa Tadeusza Sławka postulującego pracę na rzecz pedagogiki sytuacjonistycznej, którą nazywa on także pedagogiką gościnności. Jej zadaniem byłoby - jak w tytule eseju badacza - podtrzymywanie kultury nadziei, tę zaś Sławek definiuje jako między innymi odmowę zgody na bycie wciagniętym $w$ zastany stan rzeczy ${ }^{2}$. W określeniu pedagogiki jako sytuacjonistycznejoprócz odwołania do myśli Guy Deborda - pobrzmiewa przekonanie o tym, że początkiem nauk o wychowaniu jest zawsze człowiek w sy tuacji. A więc nie abstrakcyjna jednostka wypreparowana $z$ otuliny zdarzeń, lecz indywiduum zwiazane, nieodzownie i nieuchronnie zaangażowane wotaczajacy świat ${ }^{3}$. Warunkiem zaistnienia nadziei jest poczucie „nieswojości”, niezgoda człowieka na bycie wrzuconym w świat kierowany przypadkiem, co chwila stawiającym go wobec zmian wstrząsających porządkiem rzeczy (katastroficznych ${ }^{4}$ ). Celem pedagogiki opisywanej przez filozofa i literaturoznawcę byłoby ponadto konsolidowanie świata w kruche i nietrwałe konstelacje, za które jesteśmy odpowiedzialni ${ }^{5}$, a zatem wychowywanie uczącego się, by zauważał wokół siebie relacje będące rezultatem wydarzeń przypadkowych, aby czuł sprawczość wobec otaczającego środowiska oraz miał świadomość, że jest tego środowiska częścią. Narzędziami takiej nauki natomiast byłyby według filozofa wspólnie rozum i wyobraźnia 6 .

Działania podejmowane na gruncie pedagogiki sytuacjonistycznej Sławek rozważa wobec pytania: czy możliwe jest dzisiaj kształtowanie tragicznej wizji życia? 
Odpowiada na nie twierdząco, argumentując, że nauczanie i wychowanie powinno się zaczynać od poczucia straty powodującego wrażenie nietożsamości ze światem i daną sytuacją a także będącego źródłem tragizmu. W człowieku, który zdaje sobie sprawę z tragiczności swego losu, nadzieja pozwala myśleć o możliwości odwołania tego-co-jest, a zatem otwiera możliwość myślenia świata innego niż ten, który przedstawia się jako jedynie możliwy i jedyny dopuszczalny ${ }^{8}$. Zatem edukacja oparta na nadziei nie tylko pozwalałaby zdobywać wiedzę i rozwijać umiejętności, ale również przyczyniałaby się do głębokiego poznania siebie i rozpoznania sprzężenia między sobą a światem, kształtowania poczucia wolności i otwarcia na zmianę.

Przemyślenie szerszego kontekstu nauczania wydaje mi się niezbędne w przypadku refleksji nad edukacją filmową. Akademicki namysł nad tym zjawiskiem uwzględnia zwykle perspektywę oglądu filmu jako dzieła sztuki lub nauczania języka filmu w obrębie szkoły i poza nią, kształtowania kultury filmowej, modelowania postaw odbiorczych, wychowania oraz związków zajęć o filmie z szerzej rozumianym alfabetyzmem medialnym ${ }^{9}$. Brakuje natomiast ujęć teoretycznych i oceny istniejących inicjatyw w odniesieniu do zmieniającej się i aktualizującej refleksji humanistycznej. Nowa humanistyka przekracza granice dyscyplin, prowadzi dialog z naukami ścisłymi, cyfrowością sferą zaangażowania społecznego oraz rozważaniami posthumanistycznymi, rezonuje także $\mathrm{w}$ reagującej dynamicznie dydaktyce humanistycznej. Ryszard Nycz opisuje ją jako miejsce przepływów, splotów i powiązań: Świat nowej humanistyki to, po pierwsze i przede wszystkim, świat immanencji, rzeczywistość partycypacji, poznania od wewnatrz, poznania uczestniczacego ${ }^{10}$. W tak zakreślonej kulturze partycypacji nie możemy być tylko obserwatorami, wymaga ona od nas działania i zaangażowania etycznego.

Na gruncie dydaktyki ważne są rozpoznania Nycza dotyczące nurtu zaangażowanego, ściśle związanego z przekazywaniem wiedzy zdobytej w badaniach humanistycznych. Literaturoznawca opisuje jego najważniejsze aspekty, uwidaczniające się w strategiach dydaktycznych: Ucza (uczyć mają) kreatywnej lektury, angażującej nie tylko wiedzę, ale też doświadczenie oraz inwencję i wyobraźnię odbiorcy. Zachęcaja do rozwijania "wiedzy jak", umiejętności "technicznych" i narzędziowych, radzenia sobie w sytuacjach ryzyka (eksperymentalnych), krytyczności wobec pewników i dogmatów, do sprawczej partycypacji w rzeczywistości kulturowej, społecznej czy politycznej ${ }^{11}$. Ten kontekst wydaje się bardzo istotny dla edukacji filmowej, którą traktuję tu jako część kształcenia humanistycznego. Wpływają na nie nowe dyskursy akademickie, doceniające aplikatywność teorii i ścisły związek z praktyka, również dydaktyczną. Nycz podkreśla, że humanistyka zaangażowana prowadzi do uczenia, jak włączać się w życie społeczne, obywatelskie i polityczne. To istotne wyzwania, stojące także przed edukacją filmowa, zwłaszcza współcześnie, kiedy wykorzystanie filmowych historii i środków wyrazu może pomóc kształtować u uczących się otwartość na Innego, a także ćwiczyć wyobraźnię i tworzyć scenariusze dla przyszłości, które można zrealizować lub którym należy zapobiec.

\section{Studium przypadku: Centralny Gabinet Edukacji Filmowej}

Stan badań nad historią i teorią edukacji filmowej w Polsce przybliżyła w przekrojowym szkicu z 2016 r. łódzka filmoznawczyni Ewa Ciszewska ${ }^{12}$; ob- 
szerniejsze opracowania tematu znajdziemy także m.in. w książkach dydaktyków polonistycznych: Witolda Bobińskiego ${ }^{13}$ i Marii Szoski ${ }^{14}$. W obydwu wydawnictwach badacze skupiają się jednak przede wszystkim na relacjach filmu i szkolnych programów nauczania języka polskiego ${ }^{15}$ oraz uzupełniają rozprawy teoretyczne praktycznymi pomysłami włączenia filmu w lekcje szkolne. Wynika to z uwarunkowań historycznych i dominującego w Polsce „przyliterackiego” modelu edukacji filmowej, wywodzącego się jeszcze z myśli lat 30. i wpisującego zagadnienia wiedzy o filmie w program nauczania języka ojczystego, poświęcony w przeważającej mierze literaturze ${ }^{16}$. Wśród publikacji są również analizy programu Filmoteka Szkolna (opracowanego z dbałością o zgodność z wymogami szkoły) ${ }^{17}$ oraz innych programów edukacji filmowej realizowanych w kinach (Nowe Horyzonty Edukacji Filmowej, KinoSzkoła, Akademia Filmowa Multikina itd.) ${ }^{18}$, teksty poświęcone kształceniu nauczycieli ${ }^{19}$, a także nieliczne szkice dotyczące edukacji filmowej poza szkołą ${ }^{20}$. Jak wskazuje Ciszewska, artykuły naukowe są rozproszone w książkach i czasopismach dotyczących przede wszystkim trzech dyscyplin: filmoznawstwa, polonistyki i pedagogiki ${ }^{21}$, co utrudnia docieranie do materiałów, ale świadczy o interdyscyplinarności refleksji. W tym kontekście zastanawia brak szerszego zestawienia treści filmoznawczych obecnych w podręcznikach szkolnych, nie tylko tych do języka polskiego, ale przede wszystkim tych do wprowadzonego w roku szkolnym 2002/2003 na IV etapie edukacyjnym przedmiotu wiedza o kulturze, który od roku 2019/2020 w nowych szkołach średnich już nie jest nauczany ${ }^{22}$. W podstawie programowej WOK-u z 2012 r. zostało zawarte m.in. założenie, że przedmiot jest dopetnieniem kształcenia artystycznego; obejmuje ona również analizę i interpretację dzieł filmowych, znajomość najważniejszych twórców i filmów, rozpoznawanie praktyk odbioru ${ }^{23}$. Za pewną wyspecjalizowaną dziedzinę edukacji filmowej możemy uznać rozwijającą się w Polsce filmoterapię, której naukowe opracowanie przedstawiła Małgorzata Kozubek ${ }^{24}$; praktyką na tym obszarze zajmują się m.in.: zespół fundacji Generator ${ }^{25}$, Martyna Harland ${ }^{26}$, Ewa Warmuz-Warmuzińska.

Pośród wielu analiz i komentarzy do ewoluujących programów Eweliny Nurczyńskiej-Fidelskiej" ${ }^{27}$ zaskakuje także brak publikacji poświęconych Centralnemu Gabinetowi Edukacji Filmowej, powołanemu z inicjatywy łódzkiej polonistki i filmoznawczyni oraz jej mentora Bolesława W. Lewickiego w 1985 r. Od momentu powstania do 2018 r. placówką kierowała Ewa Kanownik. CGEF jest komórką Pałacu Młodzieży im. Juliana Tuwima w Łodzi. Zespół tworzą obecnie cztery osoby: Anna Kołodziejczak, Dorota Gołębiowska, Jadwiga Mostowska oraz Marta Kasprzak. Od początku działania Gabinet łączy pracę akademików i dydaktyków, filmoznawców i nauczycieli (w większości polonistów, choć nie tylko), a jego inicjatywy są kierowane przede wszystkim do tych drugich. Można go uznać za jedną z najważniejszych placówek doskonalących i wspierających pedagogów w zdobywaniu i poszerzaniu umiejętności potrzebnych w nauczaniu o filmie, przez film i do filmu. Pracownice ośrodka opiniują podstawę programowa, programy edukacji filmowej realizowane w szkołach i poza nimi oraz współpracują z Ogólnopolskim Stowarzyszeniem Kadr Kierowniczych Oświaty.

Jak podkreśla Anna Kołodziejczak: Akademicka refleksja filmoznawcza wptywa w bardzo znacznym stopniu na kierunki i tematyke podejmowanych przez nas działań. Wiąże się przecież z najnowszym stanem wiedzy w tej dziedzinie, której przekazanie pol- 
skim nauczycielom i edukatorom filmowym jest jednym z głównych zadań Gabinetu. (...) Natomiast generowana na polskich uniwersytetach refleksję dotyczaca samej edukacji filmowej - jej metod, form - uważamy za dalece niewystarczajaca. Wydaje się, że ten obszar dla naszych naukowców to "terra incognita"28. Liczne aktywności Gabinetu, który w 2020 r. obchodzi 35-lecie pracy, dowodzą realizacji przekonania o istotności związków między akademią a szkoła, naukową teorią edukacji filmowej a szkolną i pozaszkolną praktyką dydaktyczną. O sile tych relacji wspomina Ciszewska ${ }^{29}$, natomiast metodyczka i filmoznawczyni Anna Równy podkreśla rolę CGEF w doskonaleniu i dokształcaniu nauczycieli ${ }^{30}$, kwalifikując jego działania jako pozaakademickie, acz mające charakter systemowy ${ }^{31}$. Te uwagi, choć ważne i powiązane z diagnozą stanu polskiej edukacji filmowej, są jednak incydentalne, dlatego też pragnę poświęcić nieco więcej miejsca na wskazanie i omówienie najważniejszych nurtów działalności CGEF, które w mojej ocenie są przykładem stosowania osiągnięć nauki (humanistyki, ale też innych dyscyplin, np. filozofii, historii, etyki, estetyki, ekologii) w praktyce edukacyjnej.

Źródła programu CGEF to „przyliterackie” programy kształcenia filmowego postulowane przez Lewickiego, a następnie kontynuowane przez Nurczyńską-Fidelską która aż do 2016 r. była konsultantką naukową ośrodka ${ }^{32}$. Dla porządku przypomnę skrótowo najważniejsze dokonania inicjatorki Gabinetu. Pod koniec lat 60. Nurczyńska-Fidelska opracowywała programy kształcenia o filmie w ramach edukacji polonistycznej ${ }^{33}$, wspólnie z Lewickim tworzyła też ramy dla wiedzy o filmie i telewizji na lekcjach polskiego w szkole dziesięcioletniej ${ }^{34}$, a w drugiej połowie lat 80. kierowała zespołem nauczycielek polonistek w eksperymencie wdrażającym film do szkoły na mocy podstawy programowej zatwierdzonej w roku 1985. Zwłaszcza to ostatnie działanie zaważyło na ukształtowaniu się polskiego modelu szkolnej edukacji filmowej, któremu towarzyszyło przekonanie o konieczności włączenia do procesu dydaktycznego przejawów wszelkich poziomów kultury, także tych określanych jako "masowe" $i$ "niższe"35. Podjęte prace (koncepcja teoretyczna i metodyczna, lekcje prowadzone w szkołach i opublikowane scenariusze ${ }^{36}$ ) często sytuowały film w centrum uwagi podczas lekcji języka polskiego, co stanowiło novum w literaturocentrycznej tradycji. Warto też nadmienić, że Nurczyńska-Fidelska rozumiała edukację filmową jako proces odbywający się nie tylko w szkole, o czym świadczy jej współpraca z DKF-ami oraz Siecią Kin Studyjnych i Lokalnych ${ }^{37}$. Naukowa i dydaktyczna biografia Nurczyńskiej-Fidelskiej zadecydowała również o „przyliterackim” sprofilowaniu działań CGEF w początkowym okresie istnienia.

Gabinet nadal proponuje nauczycielom zajęcia możliwe do włączenia do programu lekcji (nie tylko języka polskiego), ponieważ jako placówka oświatowa reaguje na zmieniające się podstawy programowe. Edukatorki związane z instytucją przygotowują m.in. przewodniki po nowych podstawach programowych, analizując, które zapisy tych dokumentów pozwalają na wprowadzenie do szkoły filmu ${ }^{38}$, co stanowi wartość i wsparcie także dla dyrektorów szkół i placówek oświatowych. Pośród publikacji (drukowanych i internetowych) przygotowywanych przez pracownice ośrodka oraz współpracujących z nimi akademików i nauczycieli znajdują się także szczegółowe scenariusze lekcji oraz analizy filmoznawcze, możemy zatem mówić o spójnym i konsekwentnym realizowaniu misji tworzenia zasobów dla pedagogów. Z biegiem czasu oprócz materiałów dydaktycznych 
poświęconych kształceniu literackiemu pojawiły się także takie, jakie propagowały nurt wychowawczy w edukacji filmowej i były kontynuacją tradycji wychowania przez film Henryka Depty. Co ważne, owe propozycje zajęć i omówienia filmów istotnych z punktu widzenia wychowania są skierowane nie tylko do nauczycieli, ale też do rodziców młodych widzów, dzięki czemu Gabinet włącza się w misję edukacji rozumianej całościowo, przyznającej ważną rolę w procesie dydaktycznym zarówno pedagogom, jak i rodzinom.

Od 1991 r. z inicjatywy ośrodka odbywają się Ogólnopolskie Konferencje Filmoznawcze (do 2010 r. w Borkach, następnie w Radziejowicach), których oferta jest tworzona z myślą o nauczycielach oraz ich potrzebach w zakresie wiedzy o filmie, metodyki edukacji filmowej oraz wychowawczych i terapeutycznych aspektów pracy z filmem. Ciszewska podkreśla, że jest to unikatowe w skali Polski wydarzenie ${ }^{39}$, podczas którego wykłady filmoznawców są uzupełniane wystąpieniami nauczycieli, metodyków i psychologów, a także spotkaniami z filmowcami. Każda konferencja ma temat przewodni, a przegląd zagadnień poruszonych dotychczas dowodzi, jak szerokie są horyzonty twórców programu wydarzenia. Tematy można podzielić na kilka kategorii: analityczno-interpretacyjną (Sztuka interpretacji klasycznych i współczesnych dzieł filmowych - 1994; Wokót problemów adaptacji filmowej - 1997; Problemy analizy i interpretacji filmu i innych tekstów audiowizualnych - 2003; Twórczość filmowa Andrzeja Wajdy, Andrzeja Munka, Krzysztofa Kieślowskiego, Krzysztofa Zanussiego - horyzont interpretacyjny nakreślony przez nowa podstawe programowa kształcenia ogólnego - 2013), kulturoznawczą (Edukacja filmowa w kontekście przeobrażeń kultury wspótczesnej - 1991; Świadomość wielobarwności kultury jako czynnik kształcenia i wychowania. O kinie przełomu wieków - 2002; Po transformacji - rzeczywistość przedstawiona w filmach krajów postkomunistycznych - 2012), historycznofilmową (Antypody wspótczesnego kina: od "Caravaggia" do „Batmana" 1992; W stulecie kina. Sztuka filmowa w Polsce - 1996; Młode kino polskie - 2005), medioznawczą (Media a przemoc - 1998; Wszyscy jesteśmy telewidzami - 2001; Film jako baza edukacji artystycznej i medialnej - 2017).

W ciągu trzech dekad cele i sposób organizacji wydarzenia ewoluowały: $z a$ wiera więcej modułów przygotowywanych przez nauczycieli i edukatorów, pokazując, jak w innowacyjny sposób, często przy zastosowaniu najnowszych technologii, wykorzystać film w pracy na różnych etapach nauczania. Do metod wykładowych dołaczyły te aktywizujace uczestników, jak warsztat, gra, "close reading”, giełda pomysłów. (...) Konferencja nie tyle uczy i przeciera szlaki, ile raczej inspiruje do samodzielnych poszukiwań, popularyzuje wiedzę, integruje środowisko, dostarcza informacji na temat dziatań z zakresu edukacji filmowej dostępnych w Polsce ${ }^{40}$. Warto podkreślić, że wspomniana integracja środowisk jest tu kluczowa, aby akademickie ustalenia i obserwacje nie pozostawały zamknięte w dyskursie naukowym, lecz przekładały się na praktykę dydaktyczną. Dlatego też Gabinet konsekwentnie buduje mosty między uniwersytetem, szkołą a branżą kinematograficzna, dbając o wzajemne poznanie potrzeb i oczekiwań każdej z tych grup, których aktywność jest w różnym stopniu zorientowana na edukację. Od dziesięciu lat po każdej konferencji jest publikowany zbiór scenariuszy lekcji i esejów analityczno-interpretacyjnych (Zoom. Kino w zbliżeniu), który dokumentuje przedstawione na forum rozpoznania i pomysły. Jeśli chodzi o publikacje drukowane, warto też wspomnieć o nowszych seriach: Filmowe fale historii, Filmowe małe ojczyzny czy Warszawskie fale historii. Dwa pierwsze zbiory 
tekstów są pokłosiem projektów edukacyjno-kulturalnych współrealizowanych przez CGEF i Filmotekę Narodową - Instytut Audiowizualny oraz Warszawskie Centrum Innowacji Edukacyjno-Społecznych, kierowanych do uczniów i wpisujących się w założenia edukacji historycznej, regionalnej i kulturowej.

Gabinet organizuje również liczne wydarzenia dla uczniów: konkursy (Wojewódzki Interdyscyplinarny Konkurs Wiedzy o Filmie i Mediach „Filmowe łódzkie - filmowe regiony Polski”, ,Dwa srebrne ekrany”, ,Filmowe pojedynki”) oraz warsztaty. Autorki tych pomysłów starają się łączyć formalny i nieformalny wymiar edukacji, wprowadzając młodych widzów w świat kultury filmowej, wyrabiając zwyczaj chodzenia do kina i stwarzając możliwości praktycznej nauki: Choć prowadzone przez nas zajęcia nierzadko maja na celu zapoznanie uczniów z zalecanymi w podstawie programowej dziełami filmowymi (...) chętnie sięgamy także do bieżacego repertuaru kinowego i organizujemy różnorodne formy zajęć filmowych. Młodzież z całej Polski przyjeżdża do Łodzi na filmowe „zielone szkoły” (...). Bardzo dużym zainteresowaniem ciesza się zajęcia praktyczne: warsztaty realizacji filmowej, w trakcie których uczestnicy - pod opieka wykładowców i absolwentów PWSFTviT - tworza etiudę filmowa, a także warsztaty animacji poklatkowej ${ }^{41}$. Wymienione inicjatywy zatem nie tylko rozwijają umiejętność krytycznej analizy filmu, lecz także zwiększają kompetencje kulturowe oraz umożliwiają poznanie podstaw warsztatu realizatorskiego, co w scyfryzowanym świecie wydaje się szczególnie praktyczne, biorąc pod uwagę ofertę filmową w Internecie oraz możliwości technologiczne nawet najprostszych smartfonów.

Od 2010 r. działa wortal EdukacjaFilmowa.pl ${ }^{42}$, redagowany przez Gabinet, a wydawany obecnie przez FINA oraz Stowarzyszenie Edukacyjno-Kulturalne „Venae Artis”. W ciągu dekady stał się on głównym medium publikowania i rozpowszechniania treści przygotowywanych przez edukatorki Gabinetu i współpracujących z nimi autorów. Liczby są imponujące: rocznie to przynajmniej dwanaście scenariuszy lekcji, dwanaście analiz filmowych, dwadzieścia cztery teksty popularyzujace specjalistyczna wiedze o filmie (np. warsztat operatorski), dwanaście artykułów z cyklu "Seans rodzinny", które zachęcaja do rodzinnych wyjść do kina i rozmów na tematy filmowe i wychowawcze po seansach, sto cztery "Polecane premiery", czyli omówienia pod kątem edukacyjnym nowości kinowych, około trzydziestu felietonów, omówień polecanych książek, wydarzeń i imprez ${ }^{43}$. Zakładki wortalu pokazują jak bardzo powiększyło się od 1985 r. grono odbiorców Gabinetu. Znajdują się w nich materiały przeznaczone dla nauczycieli, pracowników kin, młodych kinomanów oraz rodziców. Współpraca z kiniarzami i dystrybutorami jest kontynuacją działań Nurczyńskiej-Fidelskiej, ale wciąż pozostaje aktywnością pionierską i unikatową w skali kraju. Doświadczenie oraz przygotowanie merytoryczne osób współtworzących Gabinet jest bardzo potrzebne, aby rozwijały się inicjatywy edukacyjne podejmowane przez dystrybutorów ${ }^{44}$.

Słabym punktem polskiego dyskursu o edukacji filmowej jest według Ciszewskiej dysproporcja pomiędzy stosunkowo rozbudowana sfera postulatywna a nikła obecnościa tekstów dokonujących ocen i podsumowań wdrażanych programów ${ }^{45}$. Zdaję sobie sprawę, że również ten artykuł skupia się bardziej na założeniach i ideałach niż na wynikach badań i ich ewaluacji. Pięć lat po publikacji eseju łódzkiej filmoznawczyni wciąż nie podejmuje się takich przedsięwzięć. Należy jednak zaznaczyć, że Centralny Gabinet Edukacji Filmowej każdorazowo gromadzi oceny 
uczestników swoich wydarzeń, które są następnie analizowane (choć już nie upowszechniane).

Ten - zaledwie pobieżny - przegląd licznych ścieżek działania wytyczanych od 35 lat przez Centralny Gabinet Edukacji Filmowej dowodzi nieustannego rozwoju i doskonalenia ośrodka, który nie tylko pozostaje czujny na zmiany w polskim systemie oświaty, ale także śledzi światowe tendencje w edukacji medialnej. W polskojęzycznym dyskursie o edukacji filmowej pojawiły się m.in. ustalenia opublikowane we Framework for Film Education in Europe ${ }^{46}$ (Ramy dla edukacji filmowej w Europie) ${ }^{47}$. Opracowany przez grupę ekspertów pod przewodnictwem British Film Institute dokument zakreśla szerokie pole działania w zakresie edukacji filmowej, definiując jej trzy najważniejsze wymiary: kreatywny, krytyczny oraz kulturowy. Według jego założeń uczący się: myślą krytycznie, angażują się w życie kulturalne i społeczne, są empatyczni, mają poczucie sprawczości, wykazują się postawą obywatelską. W tym celu wyróżnia się sześć obszarów uczenia się: poznawanie specyfiki filmu i charakteru procesów towarzyszących jego powstawaniu, formułowanie wypowiedzi krytycznych, zaangażowane uczestnictwo w kulturze filmowej, umieszczanie poznawanych filmów w kontekście historycznym i instytucjonalnym oraz ćwiczenie refleksyjnego, świadomego kształcenia. Główny cel określony przez brytyjskie wydawnictwo jest jasny i realny do osiągnięcia: inspirować i dać ludziom w całej Europie przez całe życie możliwość dostępu, przyjemności, rozumienia, kreowania, eksplorowania i dzielenia się filmem w jego wszystkich formach ${ }^{48}$. Różne aktywności i formy nauczania podejmowane przez Gabinet stanowią szerokie spektrum działań zmierzających do osiągnięcia tego celu. Należy także podkreślić, że propozycje edukacji filmowej wychodzące poza aspekt krytyczny (analityczno-interpretacyjny) pojawiły się w łódzkim ośrodku bardzo wcześnie. Zajęcia praktyczne są organizowane zarówno dla nauczycieli, jak i uczniów. Aspekt kulturowy edukacji filmowej jest natomiast obecny we wszystkich przedsięwzięciach, które osadzają zajęcia o filmie w kontekstach historii lokalnej i globalnej, nauk społecznych oraz innych dyscyplin.

\section{Centralny Gabinet Edukacji Filmowej z perspektywy badań nad edukacją filmową}

W podsumowaniu europejskich badań Screening Literacy pod przewodnictwem BFI w 2012 r. wskazano, że Gabinet z powodzeniem łączy wymiar krytyczny z kreatywnym, m.in. podczas filmowych zielonych szkół ${ }^{49}$. W projektach związanych z lokalnym dziedzictwem, propagowaniem chodzenia do kina oraz innymi formami łączenia seansu filmowego $\mathrm{z}$ aktywnym uczestnictwem w kulturze edukatorki CGEF realizują natomiast cele należące do wymiaru kulturowego. Chciałabym podkreślić, że projektowane przez BFI doświadczenia związane z edukacją filmową i cechy, które winny zostać wykształcone w odbiorcach w procesie edukacyjnym są w dużej mierze zbieżne z postulatem kształcenia humanistycznego w służbie demokracji i postawy obywatelskiej Marthy Nussbaum ${ }^{50}$. Proponowane przez CGEF działania nie tylko zatem wpisują się w ramy europejskiej edukacji filmowej, lecz także pozwalają osiągnąć (obywatelom - nauczycielom i uczniom) korzyści wykraczające poza cele stawiane w ministerialnej podstawie programowej czy katalogach kompetencji medialnych i filmowych. 
Do niedawna zresztą dokument Framework... był w zasadzie jedynym narzędziem konstruowania oceny istniejących i formułowania nowych programów edukacji filmowej w Polsce. Dopiero w 2019 r. z inicjatywy Narodowego Centrum Kultury Filmowej w Łodzi zespół ekspertek (Justyna Hanna Budzik, Anna Równy i Małgorzata Kozubek) opracował katalog kompetencji uwzględniających umiejętności, wiedzę, kompetencje społeczne w obszarze edukacji audiowizualnej (z naciskiem na praktyczne umiejętności i edukację filmowa ${ }^{51}$, podzielony według poziomów edukacji. W zamierzeniu ma on wyznaczać pole różnorodnych działań edukacyjnych, które obejmowałyby zarówno przekazywanie wiedzy o filmie, uczenie praktycznego warsztatu realizatorskiego, jak i rozwijanie kompetencji miękkich, a przede wszystkim wykształcenie młodych ludzi: świadomych, uważnych, wrażliwych na potrzeby innych, dla których doświadczenia z tekstami audiowizualnymi będą podstawą rozwoju krytycznego myślenia, otwarcia na świat i inspiracją do świadomego działania. Redakcja katalogu została poprzedzona badaniami (ilościowymi i jakościowymi) w grupie ponad 200 uczniów łódzkich szkół, jednak próba ta wydaje się zbyt mała, by można było mówić o wieloaspektowej i kompletnej diagnozie dotyczącej tego, co uczniowie wiedzą o filmie, jak rozumieją kino, jakie znaczenie przypisują kulturze filmowej. Analizując i komentując wyniki badania podczas pracy nad opracowaniem katalogu umiejętności, starałam się zaznaczyć, jakie działania należałoby traktować jako fundamentalne i niezbędne dla wszechstronnej edukacji filmowej ${ }^{52}$. Porównanie tych rekomendacji z 35-letnią praktyką edukacyjną Centralnego Gabinetu Edukacji Filmowej dowodzi, że łódzki ośrodek od początku rozwijał strategie dydaktyczne zmierzające do kształtowania zdolności analityczno-interpretacyjnych, tworzenia kultury filmowej oraz przekazywania umiejętności praktycznych ${ }^{53}$.

Z raportu wynika m.in. to, że uczennice i uczniowie z najmłodszej grupy wiekowej potrafią odtworzyć fabułę filmu oraz samodzielnie ułożyć prostą historię, jednak skonstruowanie narracji alternatywnej lub zagłębienie się w motywacje bohaterów i świat pozaekranowy sprawia im trudność. Wydaje się zatem, że warto wykorzystywać to skupienie najmłodszych na zawartości przekazu audiowizualnego, by od początku edukacji filmowej kształtować ich uwagę na to, co postrzegają oraz pomagać w koncentracji na przedmiocie percepcji. Wydany drukiem w 2017 r. i zamieszczony na wortalu Edukacja Filmowa Elementarz młodego kinomana autorstwa Jadwigi Mostowskiej ${ }^{54}$ może być tu cenną pomocą dydaktyczna, a opracowania recenzyjne polecanych premier i scenariusze lekcji dla najmłodszych mogą pomóc nauczycielom w ukierunkowaniu uwagi dziecięcych widzów.

Z kolei licealistki i licealiści potrzebują wsparcia nauczycielki/-a w przeprowadzeniu pogłębionej analizy i interpretacji filmu, choć dysponują rozwiniętym aparatem pojęciowym z zakresu nauk o literaturze, przyswojonym $\mathrm{w}$ trakcie edukacji polonistycznej. Należałoby zatem kształcić umiejętności analityczno-interpretacyjne i krytyczne w odniesieniu do filmu równolegle z rozwijaniem ich na lekcjach poświęconych twórczości literackiej. Warto zauważyć, że program nauczania języka polskiego w szkole od lat jest podzielony na kształcenie językowe oraz literacko-kulturowe; w obrębie tego drugiego wprowadza się treści m.in. z historii sztuki. Włączenie w ten obszar filmu wydaje się więc naturalnym rozszerzeniem zintegrowanego i kompleksowego kształcenia humanistycznego, co proponuje Gabinet, którego edukatorki wczytują się wnikliwie w podstawę programową. 
Uczennice i uczniowie ze wszystkich badanych grup wiekowych postrzegają film i proces jego realizacji przede wszystkim w kontekście ekonomicznym, widząc w filmie raczej produkt niż dzieło będące wynikiem wrażliwości artystycznej reżysera i innych członków ekipy filmowej. Stosunkowo wysoką świadomość badanych dotyczącą kinematografii jako rynku należałoby wykorzystać w kształceniu praktycznych umiejętności związanych z zawodami filmowymi i funkcjonowaniem branży kinematograficznej. Tym bardziej że badani mają niepełną wiedzę o procesach produkcji filmu i roli osób wchodzących w skład grupy realizatorskiej. Może to wynikać z faktu, że w wielu przypadkach refleksja nad filmem w szkole ogranicza się do analizy i interpretacji przekazu, akcentuje ilustracyjność obrazu filmowego wobec tekstu literackiego lub jest wpisywana w paradygmat autorski, a zbyt mało uwagi poświęca się w jej obrębie specyfice branży i powiązaniu kinematografii z innymi dziedzinami twórczości i produkcji. Autorki badania nie odnoszą się jednak do przyczyn zaobserwowanego stanu rzeczy.

Kontekst komercyjny produkcji filmowej mógłby być rozpatrywany równolegle z estetycznym wymiarem filmu i związkiem kinematografii z tradycjami artystycznymi. Mimo że w szkole dominuje analiza estetyczna, w samodzielnych wypowiedziach o kinie młodzi ludzie wciąż rzadko rozpatrują je jako sztukę. Dlatego też warto byłoby połączyć obie perspektywy spojrzenia na film: ekonomiczną i artystyczną. Inspirujących wskazówek w tej perspektywie dostarczają ustalenia Alaina Bergali, francuskiego krytyka i historyka kina związanego z działem edukacji La Cinémathèque Française, a także reżysera, który w 2002 r. sformułował koncepcję wprowadzenia do szkolnego programu wychowania artystycznego we Francji komponentu filmowego ${ }^{55}$. Badacz kładzie nacisk na rozumienie filmu jako sztuki, i to sztuki o potencjale wywrotowym, wręcz anarchicznym. Poznanie arcydzieł kina, które krytycznie odnoszą się do ustalonego porządku i reguł, ma dać uczniom - być może jedyną w życiu - okazję, by doświadczyli świata widzianego oczami Innego. Analiza i interpretacja filmów - najlepiej fragmentów zestawianych ze sobą wedle podobieństw estetycznych lub tematycznych - miałaby natomiast rozsadzić ustalone $\mathrm{w}$ konserwatywnej szkole schematy studiów nad tekstami (literackimi). Bergala postuluje, aby postrzegać film przede wszystkim jako efekt procesu kreatywnego, inaczej niż w istniejącej dotychczas francuskiej tradycji rozważań nad kinem jako językiem i wehikułem przekazu ideologicznego.

Co ważne, francuski pedagog podkreśla, jak ważną rolę odgrywa kontakt z kinem już w wieku dziecięcym, jako wydarzenie, które odciska swoje piętno na kształtowaniu gustu. W działaniach łódzkiego Gabinetu są widoczne pewne zbieżności z myślą Bergali. Przede wszystkim edukatorki placówki kładą nacisk na to, by rozwijać zainteresowania kinem już u najmłodszych uczniów. W wielu opracowaniach metodycznych ośrodka film jest przedstawiany jako dziedzina sztuki, ale to tylko jedna $\mathrm{z}$ możliwych perspektyw w studiowaniu kina, bowiem CGEF czyni edukację filmową bardziej wszechstronną niż gdyby była ona tylko częścią kształcenia artystycznego ${ }^{56}$.

\section{Humanistyka (filmowo) stosowana}

Przytoczone stanowiska badaczy brytyjskich i francuskich można wpisać w szerszy kontekst badań nad nauczaniem humanistycznym w służbie kształcenia 
człowieka (obywatela) i wspólnoty, w jego wymiarze etycznym i filozoficznym. Jedną z ważniejszych cech nowej humanistyki, w której nie brakuje miejsca na dydaktykę, jest przełożenie jej ustaleń na badania i działania w innych dyscyplinach. Według Nycza aplikatywność nowej humanistyki (jak humanistyki po prostu) oznacza przede wszystkim zdolność do "przewietrzenia" i "przemeblowania" głów jednostek i zbiorowości - tyleż w sferze idei, co postaw, zachowań, sprawczych działań, emocjonalnej wrażliwośsi ${ }^{57}$. Czy nie brzmi to jak warte podjęcia wyzwanie dla zastosowania filmu w nauce i edukacji?

Powróćmy do słów Tadeusza Sławka: Pedagogika musi sprostać fundamentalnej sytuacji ludzkiej kondycji: egzystujemy nieuchronnie otoczeni i wspóttworzeni przez nieprzewidywalne przypadki i zdarzenia losu ${ }^{58}$ - jakże aktualnie brzmią one w drugiej połowie 2020 r., kiedy rzeczywistość, jaką znaliśmy (również ta edukacyjna), od kilku miesięcy wydaje się dziełem niewiarygodnego trafu, gorzkiego żartu historii. To czas, który prowokuje do przemyślenia na nowo kształtu i roli wszelkiej edukacji, w tym filmowej, tym bardziej że - zgodnie z postulatem filozofa - aktywizuje ona w równej mierze rozum (przekazuje wiedzę dotyczącą filmu oraz doskonali zdolności analityczne i interpretacyjne) i wyobraźnię (rozwijając umiejętności twórcze). Na łamach „Magazynu Stowarzyszenia Filmowców Polskich” pojawiło się opracowanie wyzwań, przed jakimi stoi edukacja filmowa w okresie pandemii. Oprócz uwag dotyczących kwestii ekonomicznych i różnych sposobów postrzegania znaczenia sektora kultury, edukatorzy filmowi zgodnie formułują rolę tradycyjnego seansu kinowego, który uniemożliwiła izolacja społeczna. Anna Równy argumentuje: Uczestnictwo w kulturze, a projekcja filmowa w kinie do niego również należy, inaczej działa na odbiorce, tym bardziej młodego adepta sztuki filmowej. Dodatkowo poprzedzona wstęn a prelekcja i dyskusja po filmie ma zupetnie inne efekty. Badania medioznawców i filmoznawców pokazuja, że magia seansu kinowego nie jest do zastąienia $w$ domu, uruchamia dodatkowe procesy, intensyfikuje doznania estetyczne i refleksje odbior$c z q^{59}$. Realizacja bardzo istotnego komponentu wielu programów edukacyjnych ${ }^{60}$ została więc zawieszona, niemniej - jak starałam się udowodnić w artykule główni propagatorzy edukacji filmowej proponują (już od lat) także inne formy nauczania o filmie, przez film i do filmu, które w okresie lockdownu związanego z pandemią zostały zintensyfikowane, a ich funkcje i efekty wymagają ponownego przemyślenia. Izolacja (i wynikające z niej zmiany w edukacji) to także najwyższy czas na wprowadzenie w życie pedagogiki sytuacjonistycznej postulowanej przez Sławka, której jednym ze sposobów realizacji wydaje się edukacja filmowa.

Związki zachodzące między założeniami nowoczesnej humanistyki a działaniami CGEF, który nie tylko buduje mosty pomiędzy dyskursem naukowym a praktyką dydaktyczna, lecz także realizuje założenia pedagogiki sytuacjonistycznej, skłaniają mnie do wniosku, że w omawianej dziedzinie praktyka nierzadko wyprzedza teorię, a erudycja i kompetencje osób odpowiedzialnych za planowanie zajęć sprawiają, że aktualne dyskursy akademickie są szybko stosowane w dydaktyce. Wracając do pytania o cele edukacji filmowej - na podstawie dotychczasowych refleksji chciałabym zaproponować pięć (pozwoliłyby one planować zajęcia poświęcone filmowi w szerszej perspektywie kształcenia humanistycznego): 1. świadome, rozumiejące bycie w świecie; 2 . poczucie sprawczości i wpływu na relacje w środowisku (kulturze i naturze albo naturokulturze); 3. samostanowienie i definiowanie własnej tożsamości w relacji ze 
światem; 4. budowanie wspólnoty; 5 . zdolność skutecznej komunikacji z innymi we wspólnocie.

Działalność oświatowa prowadzona od 35 lat przez Centralny Gabinet Edukacji Filmowej wpisuje się także w model humanistycznego kształcenia ogólnego, którego odnowienie postulują nie tylko filozofowie (jak przywoływana wcześniej Nussbaum), lecz także dydaktycy. Wybitna metodyczka nauczania języka polskiego Zofia Agnieszka Kłakówna przekonuje o konieczności powrotu do humanistyki wobec rozwoju kultury cyfrowej i usieciowionej, w której odbywa się obecnie proces dydaktyczny: Edukacja tego rodzaju ma (...) dawać narzędzia umożliwiajace samodzielna orientacje w świecie oraz jego samodzielna konceptualizację $i$ interpretację. Chodzi w niej o stawianie w centrum uwagi pytań o własna tożsamość i rozmaite przynależności, które się na nia składaja, oraz o istotę i naturé świata, w którym się żyje ${ }^{61}$. Nie ulega wątpliwości, że film - jako obiekt kształcenia - pomaga realizować te postulaty. Tym bardziej, jeśli edukacja filmowa otwiera się na różnorodne dyskursy akademickie i praktyki dydaktyczne, w których splatają się wszelkie dyscypliny nauki.

${ }^{1}$ T. Sławek, Edukacja jako tworzenie i podtrzymywanie kultury nadziei, „Rocznik Pedagogiczny" 2017, nr 40, s. 13.

2 Tamże, s. 10.

${ }^{3}$ Tamże, s. 11.

${ }^{4}$ Nawiązuję tu do wykładu Tadeusza Sławka Edukacja jako kata-strofa wygłoszonego na konferencji Dydaktyka polonistyczna i jej nauki na Uniwersytecie Śląskim w Katowicach w październiku 2019 r. Badacz objaśniał „kata-strofę” jako wstrząs, który umożliwia oduczenie się czegoś na rzecz głębokiej przemiany.

${ }^{5}$ T. Sławek, dz. cyt., s. 14.

${ }^{6}$ Zob. tamże, s. 13.

7 Tamże, s. 14 .

${ }^{8}$ Tamże, s. 17.

${ }_{9}^{9}$ Por. np. A. Burn, M. Reid, Screening Literacy: Reflecting on Models of Films Education in Europe, "Nordic Journal of Digital Literacy” 2012, t. 7, nr 4, s. 314-324. Autorzy komentują raport z badania edukacji filmowej w 32 krajach europejskich, wyróżniając trzy perspektywy: (1) istniejącej praktyki edukatorów filmowych we wszystkich sektorach krajów członkowskich; (2) szerszego rozumienia kultury filmowej i jej znaczenia; (3) relacji między alfabetyzmem filmowym a medialnym, zwłaszcza w kontekście inicjatyw Komisji Europejskiej w zakresie alfabetyzmu medialnego (tamże, s. 315).

${ }^{10}$ R. Nycz, Nowa humanistyka w Polsce: kilka bardzo subiektywnych obserwacji, koniektur, refutacji, „Teksty Drugie” 2017, nr 1, s. 37.

${ }^{11}$ Tamże, s. 26-27.
${ }^{12}$ E. Ciszewska, Edukacja filmowa w Polsce - zarys historyczny $i$ stan badań, w: Od edukacji filmowej do edukacji audiowizualnej. Teorie i praktyki, red. taż, K. Klejsa, Wydawnictwo Uniwersytetu Łódzkiego, Łódź 2016.

${ }^{13}$ Zob. W. Bobiński, Teksty w lustrze ekranu. Okotofilmowa strategia ksztatcenia literacko-kulturowego, Universitas, Kraków 2011, s. 53-110.

${ }^{14}$ M. Szoska, Trudna obecność. Film w edukacji polonistycznej a interpretacja, Wydawnictwo Uniwersytetu Gdańskiego, Gdańsk 2019, s. 17-99.

${ }^{15} \mathrm{O}$ dominacji tej perspektywy w polskim piśmiennictwie poświęconym edukacji filmowej wspomina zresztą Ciszewska, dz. cyt., s. 79.

${ }^{16}$ To jeden z czterech modeli edukacji filmowej wyróżnionych przez Janinę Koblewską-Wróblową w 1976 r. na podstawie badań strategii przyjętych w różnych krajach. Pozostałe modele to: 2) Film jako jeden z elementów nauczania różnych przedmiotów (tak zwany "model rozproszony"), 3) Film jako autonomiczny przedmiot nauczania, 4) Film jako składnik nauki o środkach masowego oddziaływania. J. Koblewska, Wspótczesne modele edukacji filmowej na świecie, w: Modele edukacji filmowej, red. J. Masłowska, Centralny Ośrodek Metodyki Upowszechniania Kultury, Warszawa 1976, s. 35.

17 Zob. N. Chojna, Jak (wy)edukować widza?, „Magazyn Filmowy SFP” 2013, nr 26, s. 18-23; M. Jakubowska, Cele edukacji filmowej w Polsce: konteksty instytucjonalne i tendencje rozwojowe, w: Od edukacji filmowej... dz. cyt., 
s. 105, 113-116; E. Ciszewska, dz. cyt.; M. Latoch-Zielińska, Edukacja filmowa z "Filmoteka Szkolna", w: Przestrzenie rzeczywiste $i$ wyobrażone. Metodyczny wielogłos o różnych przestrzeniach, red. B. Myrdzik, I. Morawska, M. Latoch-Zielińska, Wydawnictwo Uniwersytetu Marii Curie-Skłodowskiej, Lublin 2016, s. 227-237; D. Rajewicz, Edukacja przez film, "Polonistyka” 2009, nr 3, s. 58-61; M. Szoska, dz. cyt., s. 85-88; J. H. Budzik, Filmoteka Szkolna dla najmłodszych: przewodnik po świecie filmu, w: Dystrybucja filmowa. Od kina do streamingu, red. S. Rogowski, A. Wróblewska, Wydawnictwo Naukowe Semper, Warszawa (w druku).

${ }^{18}$ Zob. np. J. H. Budzik, Film Education in Cinemas - Determinants and Tendencies, „Panoptikum" 2017, nr 18, s. 157-176; J. Zabłocka-Skorek, Wychowawcza rola filmu $w$ kontekście podstawy programowej szkoty ponadgimnazjalnej, w: Od edukacji filmowej... dz. cyt.; taż, Edukacja filmowa w praktyce. Dobór filmów w Interdyscyplinarnym Programie Edukacji Filmowej "KinoSzkoła” w kontekście recepcji filmu przez młodego widza, w: Edukacja przez słowo - obraz - dźwięk, red. J. H. Budzik, I. Copik, Wydawnictwo Uniwersytetu Śląskiego, Katowice 2015.

${ }^{19}$ Zob. np. A. Równy, Doksztatcanie i doskonalenie nauczycieli w zakresie edukacji filmowej w Polsce (okres 2010-2015) oraz E. Konieczna, Uczenie (się) kina. Wstęp do badań nad kompetencjami nauczycieli - edukatorów filmowych, w: Od edukacji filmowej... dz. cyt.

${ }^{20}$ Zob. np. P. Haratyk, Amatorskie Kluby Filmowe - nieformalna edukacja filmowa okresu PRL, „Pleograf. Kwartalnik Akademii Polskiego Filmu" 2020, nr 1, http://akademiapolskiegofilmu.pl/pl/historia-polskiego-filmu/pleograf/edukacja/21/amatorskie-kluby-filmowe-nieformalna-edukacja-filmowa-okresuprl/714 (dostęp: 18.05.2020).

${ }^{21}$ Zob. E. Ciszewska, dz. cyt., s. 79.

${ }^{22}$ Zob. np. I. Kaczmarzyk, Opinia o podręczniku Zuzanny Grębeckiej, Iwony Kurz, Małgorzaty Litwinowicz-Droździel, Pawła Rodaka „Człowiek w kulturze. Podręcznik do wiedzy o kulturze (Szkoły ponadgimnazjalne. Zakres podstawowy i rozszerzony)", Wydawnictwo Szkolne PWN, Warszawa 2006, ss. 247, w: Prace komisji PAU do oceny podręczników szkolnych. Tom VIII, red. G. Chomicki, Kraków 2010, http://pau.krakow.pl/podreczniki/tom_viii/t VIII.pdf (dostęp: 11.08.2020).

${ }^{23}$ Zob. Podstawa programowa z komentarzami. Tom 7. Edukacja artystyczna w szkole podstawowej, gimnazjum i liceum, 2012, http://www.wpek.pl/pi/89438_1.pdf (dostęp: 11.08.2020).

${ }^{24}$ Zob. M. Kozubek, Filmoterapia. Teoria i praktyka, słowo/obraz terytoria, Gdańsk 2016.

${ }^{25}$ Zob. www.kinoterapia.pl

${ }^{26}$ Zob. www.filmoterapia.pl

${ }^{27}$ Zob. m.in.: W. Bobiński, dz. cyt.; M. Szoska, dz. cyt.; E. Ciszewska, dz. cyt.; M. Jakubowska, dz. cyt.

${ }^{28}$ Centrum sterowania edukacja filmowa. Z Dorota Gołęiowska, Martą Kasprzak, Anna Kołodziejczak i Jadwiga Mostowska z Centralnego Gabinetu Edukacji Filmowej w Łodzi rozmawia Justyna Hanna Budzik, „Pleograf. Kwartalnik Akademii Polskiego Filmu" 2020, nr 1, http://akademiapolskiegofilmu.pl/pl/historia-polskiego-filmu/pleograf/edukacja/21/centrum-sterowania-edukacja-filmowa-z-dorota-golebiowska-marta-kasprzak-anna-kolodziejczak-i-jadwiga-mostowska-z-centralnego-gabinetu-edukacji-filmowej-w-lodzirozmawia-justyna-hanna-budzik/725\#k3 (dostęp: 18.05.2020).

${ }^{29}$ Zob. E. Ciszewska, dz. cyt., s. 92.

${ }^{30}$ Zob. A Równy, Doksztatcanie $i$ doskonalenie nauczycieli... dz. cyt., s. 123-124.

${ }^{31}$ Taż, Edukacja filmowa w Polsce, niepublikowany tekst wykładu wygłoszonego podczas wydarzenia Filmowa EduAkcja Warszawy w grudniu 2019 r., zorganizowanego przez Warszawski Program Edukacji Kulturalnej i Centrum Kultury Filmowej im. Andrzeja Wajdy. Manuskrypt udostępniony przez autorkę.

${ }^{32}$ Zob. Centrum sterowania... dz. cyt.

${ }^{33}$ Zob. M. Szoska, dz. cyt., s. 64-69.

${ }^{34}$ Zob. tamże, s. 70-74.

${ }^{35}$ W. Bobiński, dz. cyt., s. 90.

${ }^{36}$ E. Nurczyńska-Fidelska, B. Parniewska, E. Popiel-Popiołek, H. Ulińska, Film w szkolnej edukacji humanistycznej, PWN, Warszawa - Łódź 1993.

${ }^{37}$ Zob. Centrum sterowania... dz. cyt.

${ }^{38}$ Zob. np. zbiór propozycji wykorzystania filmu w realizacji podstawy programowej z historii, etyki, języka polskiego w klasach 4-8, kształcenia w klasach 1-3; teksty umieszczone na wortalu: http://edukacjafilmowa.pl/dlanauczyciela/film-w-nowej-podstawieprogramowej/ (dostęp: 18.05.2020); D. Górecka, Film jako atrakcyjne narzedzie realizacji wymagań podstawy programowej kształcenia ogólnego, w: Edukacja filmowa na zajęciach szkolnych i pozaszkolnych. Poradnik dla dyrektorów placówek oświatowych, nauczycieli, wychowawców, edukatorów filmowych, Warszawa 2014.

${ }^{39}$ E. Ciszewska, dz. cyt., s. 92. 
${ }^{40}$ Centrum sterowania... dz. cyt.

${ }^{41}$ Tamże.

${ }^{42}$ http://edukacjafilmowa.pl/

${ }^{43}$ Tamże.

${ }^{44} \mathrm{Na}$ temat działań edukacyjnych prowadzonych przez dystrybutorów zob. A. Równy, Dystrybutorzy w stużbie edukacji filmowej, „Ekrany” 2018, nr 6, s. 13-17.

${ }^{45}$ E. Ciszewska, dz. cyt., s. 79.

${ }^{46}$ https://www.bfi.org.uk/sites/bfi.org.uk/files/downloads/\%20bfi-a-framework-forfilm-education-brochure-2015-06-12.pdf (dostęp: 18.05.2020).

${ }^{47}$ Zob. M. Jakubowska, dz. cyt.

${ }^{48}$ Tamże.

${ }^{49}$ Zob. A. Burn, M. Reid, dz. cyt., s. 319.

${ }^{50}$ Zob. M. C. Nussbaum, Nie dla zysku. Dlaczego demokracja potrzebuje humanistów, tłum. Ł. Pawłowski, Fundacja Kultura Liberalna, Warszawa 2016.

51 Alfabetyzm filmowy. Raport Narodowego Centrum Kultury Filmowej, 2019, http://lodzcityoffilm.com/wp-content/uploads/2019/12/Alfabetyzm-filmowy.-Raport-NCKF-2.pdf (dostęp: 18.05.2020).

${ }^{52}$ Przytoczę tu skrótowo najważniejsze ustalenia przede wszystkim z badania jakościowego, przeprowadzonego przez ASM Centrum Badań i Analiz Rynku Sp. z. o.o.

${ }^{53}$ Przedstawione rekomendacje i wnioski sa zmodyfikowaną wersją fragmentu niepublikowanej ekspertyzy dotyczącej mojego projektu katalogu kompetencji audiowizualnych w zakresie umiejętności, opracowanego na zlecenie NCKF.

${ }^{54}$ Zob. J. Mostowska, Elementarz młodego kinomana, Stowarzyszenie Edukacyjno-Kulturalne „Venae Artis”, Łódź 2017, http://edukacjafilmowa.pl/elementarz-mlodego-kinomana/ (dostęp: 18.05.2020).

${ }^{55}$ Zob. A. Bergala, L'hypothèse cinéma. Petit traité de transmission du cinéma à l'école et alleuirs, „Cahiers du cinéma” 2002. Szerzej analizuję propozycję Bergali w artykule Filmoteka Szkolna dla najmłodszych... dz. cyt.

${ }^{56}$ Kontekst francuski wymaga jeszcze jednego uzupełnienia. Zanim na początku XXI w. z inicjatywy ówczesnego ministra edukacji Jacka Langa powstała inicjatywa, by wiedzę o filmie (jako sztuce) włączyć do obowiązkowego programu kształcenia szkolnego, od 1994 r. funkcjonował już ogólnonarodowy fakultatywny program École au cinéma (Szkoła w kinie), nad którym pieczę sprawowało do 2018 r. Centre nationale de la cinématographie (Narodowe Centrum Kinematografii), a obecnie czyni to stowarzyszenie
Les enfants du cinéma (Dzieci Kina). Przeznaczona początkowo dla szkół podstawowych, a później również dla gimnazjalistów i licealistów, inicjatywa ma na celu zapoznanie uczniów z kinem poprzez roczny program projekcji filmowych w kinach oraz ich obudowe pedagogiczna tworzona przez nauczycieli oraz partnerów kulturalnych (https://eduscol.education.fr/cinema/enseignementdispositifs/ecole/ecole-et-cinema). W założeniach École au cinéma również dominuje definiowanie filmu jako dziedziny sztuki o cechach odróżniających ją od innych dyscyplin artystycznych. W opracowaniu corocznego repertuaru oraz pakietu materiałów dydaktycznych dla nauczycieli różnych przedmiotów biorą udział nauczyciele pracujący dla instytucji podobnych do polskich kuratoriów oświaty. W merytoryczny nadzór nad przedsięwzięciem są również zaangażowane organizacje pozarządowe. Według danych z października 2017 r. w École au cinéma brało udział aż 13,6\% uczniów francuskich podstawówek (dane ze strony http://enfants-decinema.com/ecole-et-cinema/). Mimo tego sukcesu frekwencyjnego program zawiera elementy sporne. Oprócz wspomnianego już przywiązania do definicji filmu jako sztuki, fenomenu odrębnego od codziennych form kultury audiowizualnej, są to także m.in. sprzeczność między ogólnokrajowym charakterem programu a dostosowywaniem repertuaru do potrzeb lokalnych oraz trudności związane z rozrastaniem się przedsięwzięcia, które sprawia, że coraz trudniej nim zarządzać jako tworem ogólnofrancuskim. Zob. A. Boutin, "École et cinéma": A National Model for Arts Education in Schools, "Film Education Journal" 2019, t. 2, nr 1, s. 61-70.

${ }^{57}$ R. Nycz, dz. cyt., s. 27.

${ }^{58}$ T. Sławek, dz. cyt., s. 13.

${ }^{59}$ A. Kiciński, Edukacja filmowa w czasach i po epidemii (część 2), https://www.sfp.org.pl/wydarzenia, 5,30105,1,1,Edukacja-filmowa-wczasach-i-po-epidemii-czesc-2.html?fbclid=IwAR2rnMrGdtuQBaPxr-vzWaeHGR26xNS6OQsy5TLnvVJdc9AojjTJGFJFY-U (dostęp: 18.05.2020).

${ }^{60}$ Nie tylko w Polsce, ale i na świecie propaguje się wyjścia do kina jako istotną strategię dydaktyczną i kształtowanie nawyków.

${ }^{61}$ Zob. A. Kłakówna, Idea reaktywacji ogólnego kształcenia humanistycznego. Zarys, w: Edukacja w czasach cyfrowej zarazy, red. P. Kasprzak, taż, P. Kołodziej, A. Regiewicz, J. Waligóra, Wydawnictwo Adam Marszałek, Toruń 2016, s. 139-140. 
Justyna Budzik
Doktor nauk humanistycznych, adiunkt w Instytucie Nauk o Kulturze Uniwersytetu Śląskiego. Filmoznawczyni i lektorka języka polskiego jako obcego. Autorka książek Filmowe cuda i sztuczki magiczne. Szkice z archeologii kina (2015) oraz Dotyk światta. O zmystowym doznawaniu kina (2012), współautorka (wraz z A. Tambor) publikacji Polska pótka filmowa. Krótkometrażowe filmy aktorskie $i$ animowane w nauczaniu jezyka polskiego jako obcego (2018). Lektorka języka polskiego w INALCO w Paryżu (2016/2017), laureatka Fulbright Slavic Award na University of Washington w Seattle (2017/2018). Zawodowo i badawczo zajmuje się edukacją medialną oraz glottodydaktyką polonistyczną.

\section{Bibliografia}

Bergala, A. (2002). L'hypothèse cinéma. Petit traité de transmission du cinéma à l'école et alleuirs. Paris: Cahiers du cinéma.

Bobiński, W. (2011). Teksty w lustrze ekranu. Okołofilmowa strategia kształcenia literacko-kulturowego. Kraków: Universitas.

Boutin, A. (2019). „École et cinéma”: A National Model for Arts Education in Schools. Film Education fournal, 2 (1), ss. 61-70. https://doi.org/10.18546/FEJ.02.1.05

Budzik, J. H. (2017). Film Education in Cinemas - Determinants and Tendencies. $P a-$ noptikum, 25 (18), ss. 157-176. https://doi.org/10.26881/pan.2017.18.10

Budzik, J. H. (2020). Centrum sterowania edukacją filmową. Z Dorotą Gołębiowską, Martą Kasprzak, Anną Kołodziejczak i Jadwigą Mostowską z Centralnego Gabinetu Edukacji Filmowej w Łodzi rozmawia Justyna Hanna Budzik. Pleograf. Kïartalnik Akademii Polskiego Filmu, (1). http://akademiapolskiegofilmu.pl/pl/historia-polskiego-filmu/pleograf/edukacja/21/centrum-sterowania-edukacja-filmowa-z-dorotagolebiowska-marta-kasprzak-anna-kolodziejczak-i-jadwiga-mostowska-z-centralnego-gabinetu-edukacji-filmowej-w-lodzi-rozmawia-justyna-hannabudzik/725*k3

Budzik, J. H. (2020). Filmoteka Szkolna dla najmłodszych: przewodnik po świecie filmu. W: S. Rogowski, A. Wróblewska (red.), Dystrybucja filmowa. Od kina do streamingu (wyd. 1). Warszawa: Wydawnictwo Naukowe Semper.

Burn, A., Reid M. (2012). Screening Literacy: Reflecting on Models of Films Education in Europe. Nordic Fournal of Digital Literacy, 7 (4), ss. 314-324.

Chojna, N. (2013). Jak (wy)edukować widza?. Magazyn Filmowy SFP, (26), ss. 18-23.

Ciszewska, E. (2016). Edukacja filmowa w Polsce - zarys historyczny i stan badań. W: E. Ciszewska, K. Klejsa (red.), Od edukacji filmowej do edukacji audiowizualnej. Teorie i praktyki (wyd. 1, ss. 79-98). Łódź: Wydawnictwo Uniwersytetu Łódzkiego.

Górecka, D. (2014). Film jako atrakcyjne narzędzie realizacji wymagań podstawy programowej kształcenia ogólnego. W: D. Górecka, D. Gołębiowska (red.), Edukacja filmowa na zajęciach szkolnych $i$ pozaszkolnych. Poradnik dla dyrektorów placówek 
ośziatowych, nauczycieli, wychowawców, edukatorów filmowych (wyd. 1, ss. 2-4). Warszawa: Sieć Kin Studyjnych i Lokalnych Filmoteki Narodowej.

Haratyk, P. (2020). Amatorskie Kluby Filmowe - nieformalna edukacja filmowa okresu PRL. Pleograf. Kwartalnik Akademii Polskiego Filmu, (1). http://akademiapolskiegofilmu.pl/pl/historia-polskiego-filmu/pleograf/edukacja/21/amatorskie-kluby-filmowe-nieformalna-edukacja-filmowa-okresu-prl/714

Jakubowska, M. (2016). Cele edukacji filmowej w Polsce: konteksty instytucjonalne i tendencje rozwojowe. W: E. Ciszewska, K. Klejsa (red.), Od edukacji filmowej do edukacji audiowizualnej. Teorie i praktyki (wyd. 1, ss. 99-116). Łódź: Wydawnictwo Uniwersytetu Łódzkiego.

Kaczmarzyk I. (2010). Opinia o podręczniku Zuzanny Grębeckiej, Iwony Kurz, Małgorzaty Litwinowicz-Droździel, Pawła Rodaka „Człowiek w kulturze. Podręcznik do wiedzy o kulturze (Szkoły ponadgimnazjalne. Zakres podstawowy i rozszerzony)”, Wydawnictwo Szkolne PWN, Warszawa 2006, ss. 247. W: G. Chomicki (red.), Prace komisji PAU do oceny podręczników szkolnych. Tom VIII. http://pau.krakow.pl/podreczniki/tom_viii/tVIII.pdf

Kiciński, A. (2020). Edukacja filmowa w czasach i po epidemii (cz. 2). Sfp.org.pl. https://www.sfp.org.pl/wydarzenia,5,30105,1,1,Edukacja-filmowa-w-czasach-i-poepidemii-czesc-2.html?fbclid=IwAR2rnMrGdtuQBaPxr-vzWaeHGR26xNS6OQsy5TLnvVJdc9AojjTJGFJFY-U

Kłakówna, Z. A. (2016). Idea reaktywacji ogólnego kształcenia humanistycznego. Zarys. W: P. Kasprzak, Z. A. Kłakówna, P. Kołodziej, A. Regiewicz, J. Waligóra (red.), Edukacja w czasach cyfrowej zarazy (wyd. 1, ss. 136-144). Toruń: Wydawnictwo Adam Marszałek.

Koblewska, J. (1976). Współczesne modele edukacji filmowej na świecie. W: J. Masłowska (red.), Modele edukacji filmowej (wyd. 1, ss. 31-78). Warszawa: Centralny Ośrodek Metodyki Upowszchniania Kultury.

Konieczna, E. (2016). Uczenie (się) kina. Wstęp do badań nad kompetencjami nauczycieli - edukatorów filmowych. W: E. Ciszewska, K. Klejsa (red.), Od edukacji filmowej do edukacji audiowizualnej. Téorie i praktyki (wyd. 1, ss. 143-160). Łódź: Wydawnictwo Uniwersytetu Łódzkiego.

Kozubek M. (2016). Filmoterapia. Teoria i praktyka. Gdańsk: słowo/obraz terytoria.

Latoch-Zielińska, M. (2016). Edukacja filmowa z „Filmoteką Szkolną”. W: B. Myrdzik, I. Morawska, M. Latoch-Zielińska (red.), Przestrzenie rzeczywiste i wyobrażone. Metodyczny wielogłos o różnych przestrzeniach (wyd. 1, ss. 227-237). Lublin: Wydawnictwo Uniwersytetu Marii Curie-Skłodowskiej.

Mostowska, J. (2017). Elementarz młodego kinomana. Łódź: Stowarzyszenie Edukacyjno-Kulturalne „Venae Artis”.

Nurczyńska-Fidelska, E., Parniewska, B., Popiel-Popiołek, E., Ulińska, H. (1993). Film w szkolnej edukacji humanistycznej. Warszawa: Wydawnictwo Naukowe PWN.

Nussbaum, M. C. (2016). Nie dla zysku. Dlaczego demokracja potrzebuje humanistów (thum. Ł. Pawłowski). Warszawa: Fundacja Kultura Liberalna. (Publikacja oryginału: 2010).

Nycz, R. (2017). Nowa humanistyka w Polsce: kilka bardzo subiektywnych obserwacji, koniektur, refutacji. Teksty Drugie, (1), ss. 18-40. https://doi.org/10.18318/td.2017.1.2

Pabiś-Orzeszyna, M., Fronczkowska, B. i in. (2019). Alfabetyzm filmowy. Raport $\mathrm{Na}$ rodowego Centrum Kultury Filmowej. Lodzcityoffilm.com. http://odzcityoffi$\mathrm{lm} . \mathrm{com} / \mathrm{wp}$-content/uploads/2019/12/Alfabetyzm-filmowy.-Raport-NCKF-2.pdf 
Rajewicz, D. (2009). Edukacja przez film. Polonistyka, (3), ss. 58-61.

Równy, A. (2016). Dokształcanie i doskonalenie nauczycieli w zakresie edukacji filmowej w Polsce (okres 2010-2015). W: E. Ciszewska, K. Klejsa (red.), Od edukacji filmowej do edukacji audiowizualnej. Teorie i praktyki (wyd. 1, ss. 117-130). Łódź: Wydawnictwo Uniwersytetu Łódzkiego.

Równy, A. (2018). Dystrybutorzy w służbie edukacji filmowej. Ekrany, (6), ss. 13-17.

Sławek, T. (2017). Edukacja jako tworzenie i podtrzymywanie kultury nadziei. Rocznik Pedagogiczny, (40), ss. 9-24.

Szoska, M. (2019). Trudna obecność. Film w edukacji polonistycznej a interpretacja. Gdańsk: Wydawnictwo Uniwersytetu Gdańskiego.

Zabłocka-Skorek, J. (2015). Edukacja filmowa w praktyce. Dobór filmów w Interdyscyplinarnym Programie Edukacji Filmowej „KinoSzkoła” w kontekście recepcji filmu przez młodego widza. W: J. H. Budzik, I. Copik (red.), Edukacja przez słowo obraz - ḋ́zięk (wyd. 1, ss. 110-138). Katowice: Wydawnictwo Uniwersytetu Śląskiego.

Zabłocka-Skorek, J. (2016). Wychowawcza rola filmu w kontekście podstawy programowej szkoły ponadgimnazjalnej. W: E. Ciszewska, K. Klejsa (red.), Od edukacji filmowej do edukacji audiowizualnej. Teorie i praktyki (wyd. 1, ss. 161-196). Łódź: Wydawnictwo Uniwersytetu Łódzkiego.

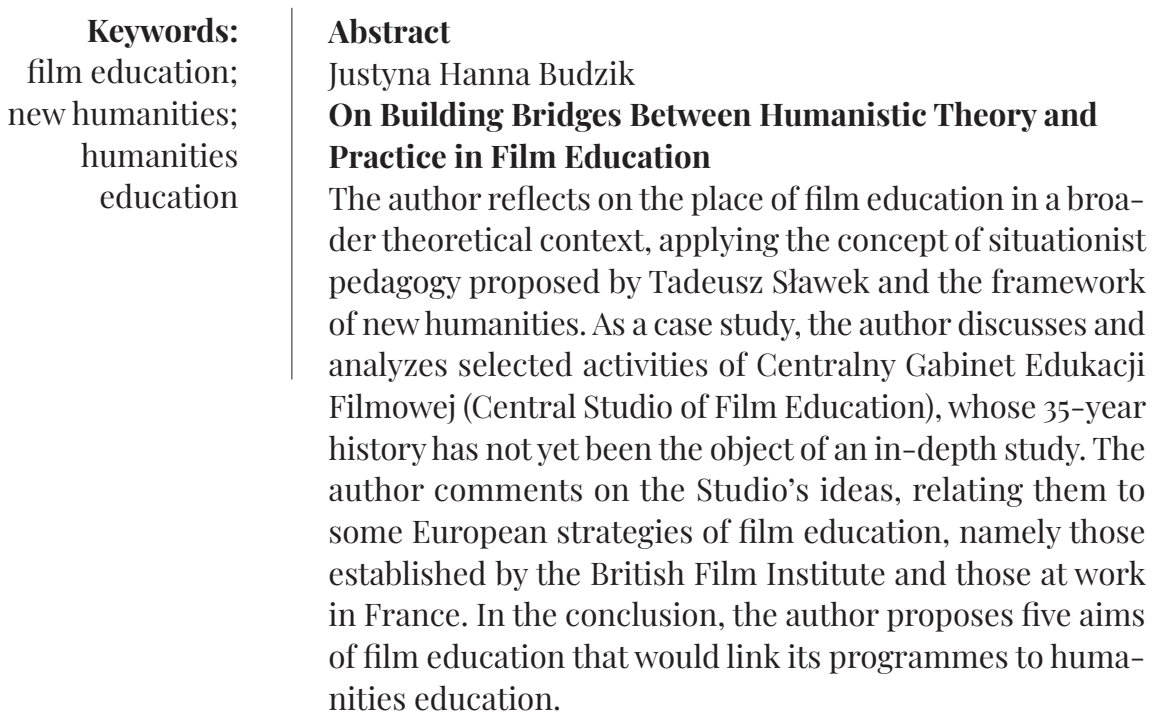

